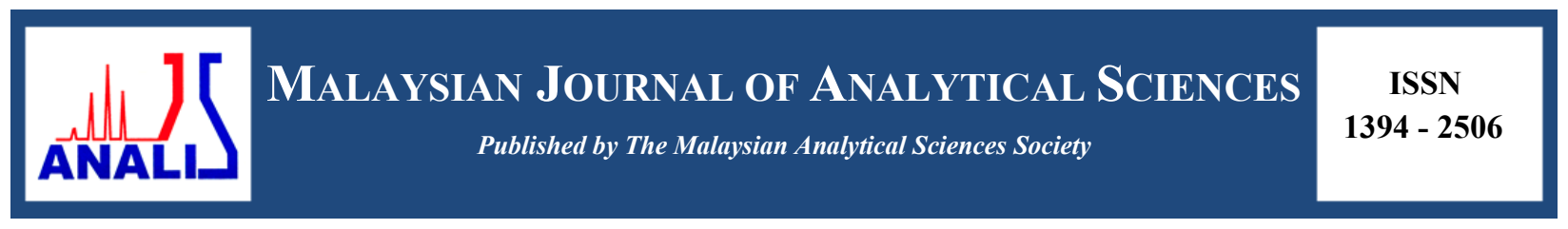

\title{
PRODUCTION OF VOLATILE ORGANIC COMPOUNDS USING OIL PALM FROND JUICE AS A SOLE SUBSTRATE BY Ceratocystis fimbriata
}

\author{
(Penghasilan Sebatian Organik Meruap Menggunakan Jus Pelepah Kelapa Sawit Sebagai \\ Substrat Tunggal oleh Ceratocystis fimbriata) \\ Nang Nor Azimah Long Nadzri ${ }^{1}$, Mior Ahmad Khushairi Mohd Zahari ${ }^{1 *}$, Saiful Nizam Tajuddin ${ }^{2}$, \\ Che Mohd Aizal Che Mohd ${ }^{2}$ \\ ${ }^{I}$ Faculty of Chemical \& Natural Resources Engineering \\ ${ }^{2}$ Bio Aromatic Research Centre of Excellence \\ Universiti Malaysia Pahang, Lebuhraya Tun Razak, 26300 Kuantan, Pahang, Malaysia \\ *Corresponding author: ahmadkhushairi@ump.edu.my
}

Received: 16 April 2017; Accepted: 7 March 2018

\begin{abstract}
In this paper, the potential of oil palm frond (OPF) juice as an alternative and renewable carbon source to replace the function of glucose to produce volatile compounds by Ceratocystis fimbriata will be reported. The OPF juice was extracted using simple physical separation method. The growths of fungi were monitored by using cell dry weight (CDW) method whereby the characterization of sugar composition and consumption of the OPF juice by Ceratocystis fimbriata were carried out using high performance liquid chromatography(HPLC). The volatile organic compounds were separated and analyzed by gas chromatography-mass spectrometry (GC-MS) with solid phase micro extraction (SPME). On the fourth day, the biomass produced by Ceratocystis fimbriata increased significantly and produced the highest number of products comprising of 3 alcohols, 2 esters, 1 aldehyde, 1 fatty acid, 1 phenol and 1 ketone. Based on the GC-MS analysis, several volatile compounds namely aldehydes, alcohols, ketones, and esters could be produced from OPF juice supplemented with a mineral salt medium. This result shows the potential usage of OPF juice as substrates for the growth and production of volatile organic compounds by Ceratocystis fimbriata.
\end{abstract}

Keywords: oil palm frond juice, volatile organic compounds, Ceratocystis fimbriata

\begin{abstract}
Abstrak
Dalam laporan ini, kajian mengenai kebolehan jus pelepah kelapa sawit (OPF) sebagai sumber karbon alternatif dan yang boleh diperbaharui telah dijalankan untuk menggantikan fungsi glukosa untuk pengeluaran sebatian meruap oleh kulat Ceratocystis fimbriata. Jus OPF diekstrak menggunakan kaedah pemisahan fizikal yang mudah. Pertumbuhan kulat dipantau menggunakan kaedah sel berat kering (CDW) manakala pencirian komposisi gula dan penggunaannya oleh Ceratocystis fimbriata di dalam jus ini telah dijalankan dengan menggunakan peralatan kromatografi cecair berprestasi tinggi (HPLC). Sebatian meruap pula dipisahkan dan dianalisis menggunakan kromatografi gas - spektrometri jisim (GC-MS) bersama pengekstrakan mikro fasa pepejal (SPME). Pada hari keempat, pengeluaran biojisim meningkat dengan ketara dan mengeluarkan produk yang paling tinggi, iaitu 3 alkohol, 2 ester, 1 aldehid, 1 asid lemak, 1 fenol dan 1 keton. Berdasarkan analisis daripada GC-MS, hasil fermentasi menunjukkan beberapa sebatian organik meruap seperti aldehid, alkohol, keton dan ester boleh dihasilkan daripada jus OPF ditambah dengan media garam mineral. Hasil daripada kajian ini menunjukkan bahawa jus OPF mempunyai potensi besar untuk digunakan sebagai substrat untuk pertumbuhan dan penghasilan sebatian organik meruap oleh Ceratosystis fimbriata.
\end{abstract}

Kata kunci: jus pelepah kelapa sawit, sebatian organik meruap, Ceratocystis fimbriata 


\section{Introduction}

In Malaysia, oil palm plantations and the palm oil industries were the main contributors to the generation of agricultural waste. From previous studies, researches have studied the potential of utilizing the agricultural waste efficiently. For example, the conversion of the oil palm empty fruit brunch (OPEFB) into fermentable sugar [1-3], utilization of the OPEFB as a substrate for enzyme production [4] and pulp preparation from OPEFB [5]. The common substrate used during fermentation is glucose where it functions as a source of energy or carbon source. In this research, oil palm frond (OPF) juice is used to replace the role of glucose during fermentation. OPF juice is reported to contain renewable sugars such as glucose, sucrose and fructose [6]. In addition to that, it was suggested that OPF juice have high potential to be used as a fermentation feedstock for the production of various value-added products such as polyhydroxyalkanoates (PHA), bioethanol, biobutanol, lactic acid, and succinic acid as it contains high amount of sugars [7]. OPF juice is expected to address the environmental issues for the production of aromatic volatile compounds as OPF is abundantly available as a biomass and easily available throughout Malaysia.

The utilization and development of volatile organic compounds (VOCs) from microorganisms have been of increasing interest as they are naturally produced without chemical synthesis. VOCs are carbon-based solids and liquids that readily enter the gas phase by vaporizing at $0.01 \mathrm{kPa}$ at a temperature of approximately $20{ }^{\circ} \mathrm{C}$ [8]. The identified VOCs generated by fungi and bacteria are mainly primary (from the synthesis of DNA, amino and fatty acids, etc.) and secondary metabolites (from intermediates of primary metabolism) [9].

Microorganisms are widely used role in the generation of natural compounds, particularly in the field of food aromas. From previous studies, filamentous fungi can be very useful in the flavor field because they are able to produce flavoring compounds and flavor related to enzyme [10]. Ceratocystis fimbriata is a mold which has the potential for synthesizing esters, it grows quickly and produces a variety of aromas (peach, pineapple, banana, citrus and rose) depending on the strain and culture conditions [11].

Therefore, in this study the ability of Ceratocystis fimbriata to produce aromatic volatile compounds by using OPF juice as a sole carbon source was investigated in the shake flask experiment. The head space-solid phase micro extraction (HS-SPME) technique combined with gas chromatography-mass spectrometry (GC-MS) was used to analyze the aromatic volatile compounds during the fermentation. To date, researches on the production of volatile compounds by Ceratocystis fimbriata from OPF juice as substrates has not been reported yet. Therefore, it is hope that this research will contribute for further investigation on the production of volatile compounds using this fungus at the commercial scale.

\section{Microorganism and culture medium}

\section{Materials and Methods}

The fungal strain Ceratocystis fimbriata (ATCC 12866) was obtained from freeze-dried microorganism purchased from American Type Culture Collection (ATCC), USA. The fungal was grown and transferred periodically onto the Potato Dextrose Agar (PDA). The seed culture was prepared after 7 days of growth at $30{ }^{\circ} \mathrm{C}$. After 7 days, the spores were collected from the surface of the plate by adding distilled water containing a few drops of Tween 80 and some glass beads. The basal growth medium consisted of glucose, $20 \mathrm{~g} / \mathrm{L}$; urea, $0.75 \mathrm{~g} / \mathrm{L}$; ammonium sulfate $\left(\left(\mathrm{NH}_{4}\right)_{2} \mathrm{SO}_{4}\right) 2.25 \mathrm{~g} / \mathrm{L}$; monopotassium phosphate $\left(\mathrm{KH}_{2} \mathrm{PO}_{4}\right) 1 \mathrm{~g} / \mathrm{L}$; calcium nitrate tetrahydrate $\left(\mathrm{Ca}\left(\mathrm{NO}_{3}\right)_{2} .4 \mathrm{H}_{2} \mathrm{O}\right)$ $0.5 \mathrm{~g} / \mathrm{L}$; magnesium sulfate heptahydrate $\left(\mathrm{MgSO}_{4} .7 \mathrm{H}_{2} \mathrm{O}\right) 0.5 \mathrm{~g} / \mathrm{L}$; trace element solution, $2 \mathrm{ml} / \mathrm{L}$. The trace element solution comprised of: Iron(III) nitrate nonahydrate $\left(\mathrm{Fe}\left(\mathrm{NO}_{3}\right)_{3} .9 \mathrm{H}_{2} \mathrm{O}\right) 723.8 \mathrm{mg} / \mathrm{L}$; zinc sulfate heptahydrate $\left(\mathrm{ZnSO}_{4} .7 \mathrm{H}_{2} \mathrm{O}\right) 439.8 \mathrm{mg} / \mathrm{L}$; manganese(II) sulfate tetrahydrate $\left(\mathrm{MnSO}_{4} \cdot 4 \mathrm{H}_{2} \mathrm{O}\right) 203 \mathrm{mg} / \mathrm{L}$. The medium was supplemented with chloramphenicol $0.5 \mathrm{~g} / \mathrm{L}$ to inhibit bacterial contamination and the $\mathrm{pH}$ was adjusted to 6.0 with sodium hydroxide $(\mathrm{NaOH}) 0.5 \mathrm{~N}$ before autoclaved at $121^{\circ} \mathrm{C}$ for 20 minutes. For the seed culture preparation, $1 \mathrm{~mL}$ of the spores were taken aseptically and transferred into $50 \mathrm{~mL}$ centrifuge tube containing $9 \mathrm{~mL}$ of basal growth medium. The seed cultures were then incubated at $27^{\circ} \mathrm{C}$ for 9 days on a rotary shaker at $(150 \mathrm{rpm})$.

\section{Substrate preparation}

The oil palm frond (OPF) juice used in this research were obtained from Lembaga Kemajuan Pertubuhan Peladang (LKPP) Oil Palm Plantation, Lepar Hilir, Gambang Pahang, Malaysia. The OPF juice was extracted by pressing the 
frond using a conventional sugarcane press machine. The OPF juice was centrifuged at 10,000 rpm for 10 minutes at $4{ }^{\circ} \mathrm{C}$. The sugar content in the OPF juice were determined by High Performance Liquid Chromatography (HPLC) (Agilent Series 1200, USA) using the Supelcosil LH-NH ${ }_{2}$ column (Sigma Aldrich) $(25 \mathrm{~cm}$ x $4.6 \mathrm{~mm}$ ID, $5 \mu \mathrm{m}$ particles) with a RI detector operated at $30{ }^{\circ} \mathrm{C}$. The mobile phase consisted of a ratio of acetonitrile: water $(75 \%$ : $25 \%$ ) at a flow rate of $1.0 \mathrm{~mL} / \mathrm{min}$.

\section{Fermentation procedure}

The experiments were done by using OPF juice containing $30 \mathrm{~g} / \mathrm{L}$ of glucose using $250 \mathrm{~mL}$ flasks and were mixed with a mineral salt medium. This medium consisted of the following composition: urea, $0.9 \mathrm{~g} / \mathrm{L} ;\left(\mathrm{NH}_{4}\right)_{2} \mathrm{SO}_{4}, 2.7$ $\mathrm{g} / \mathrm{L} ; \mathrm{KH}_{2} \mathrm{PO}_{4}, 1.2 \mathrm{~g} / \mathrm{L} ; \mathrm{Ca}\left(\mathrm{NO}_{3}\right)_{2} .4 \mathrm{H}_{2} \mathrm{O}, 0.6 \mathrm{~g} / \mathrm{L} ; \mathrm{MgSO}_{4} .7 \mathrm{H}_{2} \mathrm{O}, 0.6 \mathrm{~g} / \mathrm{L} ;$ trace element solution, $2 \mathrm{ml} / \mathrm{L}$; chloramphenicol $0.6 \mathrm{~g} / \mathrm{L}$ and the $\mathrm{pH}$ was adjusted to 6.0 with $\mathrm{NaOH} 0.5 \mathrm{~N}$ before autoclaved. The flasks were covered with cotton and sterilized at $121{ }^{\circ} \mathrm{C}$ for 20 minutes. One mycelium cell from seed cultures was taken aseptically and introduced into a $250 \mathrm{~mL}$ Erlenmeyer flask containing $100 \mathrm{~mL}$ of the synthetic medium. The fermentation was carried out at $27^{\circ} \mathrm{C}$ on a rotary shaker at $150 \mathrm{rpm}$ for 8 days.

\section{Growth determination}

The mycelia were collected at every 24 hours for 8 days after centrifugation $\left(10,000 \mathrm{rpm}\right.$ for 15 minutes at $\left.4{ }^{\circ} \mathrm{C}\right)$. The mycelia were washed twice with distilled water. The biomass was measured by the dry weight determination (24 hours in a drying oven at $100^{\circ} \mathrm{C}$ ) method.

\section{Analytical procedure}

The samples were taken periodically from the culture medium and were centrifuged at 10,000 rpm for 15 minutes at $4{ }^{\circ} \mathrm{C}$. The supernatants were filtered through a $0.22-\mu \mathrm{m}$ pore filter (Millipore) prior to analysis. The volatile compounds were detected by gas chromatography-mass spectrometry-solid phase micro extraction (GC-MS SPME). In this study, the fibre DVB-CAR-PDMS $(50 / 30 \mu \mathrm{m})$, which has been frequently employed for the extraction of the volatile fraction from natural products, was tested for the analysis of volatile compounds. The fibre was exposed to the head space (HS) for 45 minutes at $45{ }^{\circ} \mathrm{C}$. After 45 minutes, the SPME fibre was immediately inserted into the $\mathrm{GC}$ injector for 46 minutes. The desorption time of 2 minutes at $230^{\circ} \mathrm{C}$ was used in the splitless mode. Before sampling, the fibre was reconditioned for 45 minutes in the $\mathrm{GC}$ injector port at $230^{\circ} \mathrm{C}$.

\section{Glucose consumption}

The samples were taken periodically from the culture medium and the consumption of glucose by Ceratocystis fimbriata were determined by high performance liquid chromatography (HPLC) (Agilent Series 1200, USA) using the Supelcosil LH-NH ${ }_{2}$ column (Sigma Aldrich) $(25 \mathrm{~cm}$ x $4.6 \mathrm{~mm}$ ID, $5 \mu \mathrm{m}$ particles) with a RI detector operated at $30{ }^{\circ} \mathrm{C}$. The mobile phase comprised of acetonitrile: water $(75 \%: 25 \%)$ at a flow rate of $1.0 \mathrm{~mL} / \mathrm{min}$.

\section{Results and Discussion}

The results of the biomass produced by Ceratocystis fimbriata in mineral salt medium supplemented with OPF juice is shown in Figure 1. The biomass production was calculated from the first day until the eighth day of fermentation. As shown in Figure 1, it was apparent that the Ceratocystis fimbriata biomass has increased sharply from the second day to the fourth day and increased slowly thereafter. Based on the growth profile, the lag phase for Ceratocystis fimbriata began from the first day until the second day. Then, followed by the exponential phase where the productions of biomass increased significantly up to the fourth day. After that, the stationary phase started to occur slowly from the fourth day until the end of the fermentation period. On the other hand, the results of the glucose consumption of Ceratocystis fimbriata in synthetic medium supplemented with OPF juice is shown in Figure 2. The glucose consumption was analysed from the first day of fermentation until the eighth day. In Figure 2, the glucose consumption of Ceratocystis fimbriata decreased sharply from second day to the fourth day of fermentation period and decrease slowly thereafter as it was consumed by the fungus. With reference to Figure 1 and Figure 2, it was shown that the biomass production profile is consistent with the glucose consumption profile by Ceratocystis fimbriata. 


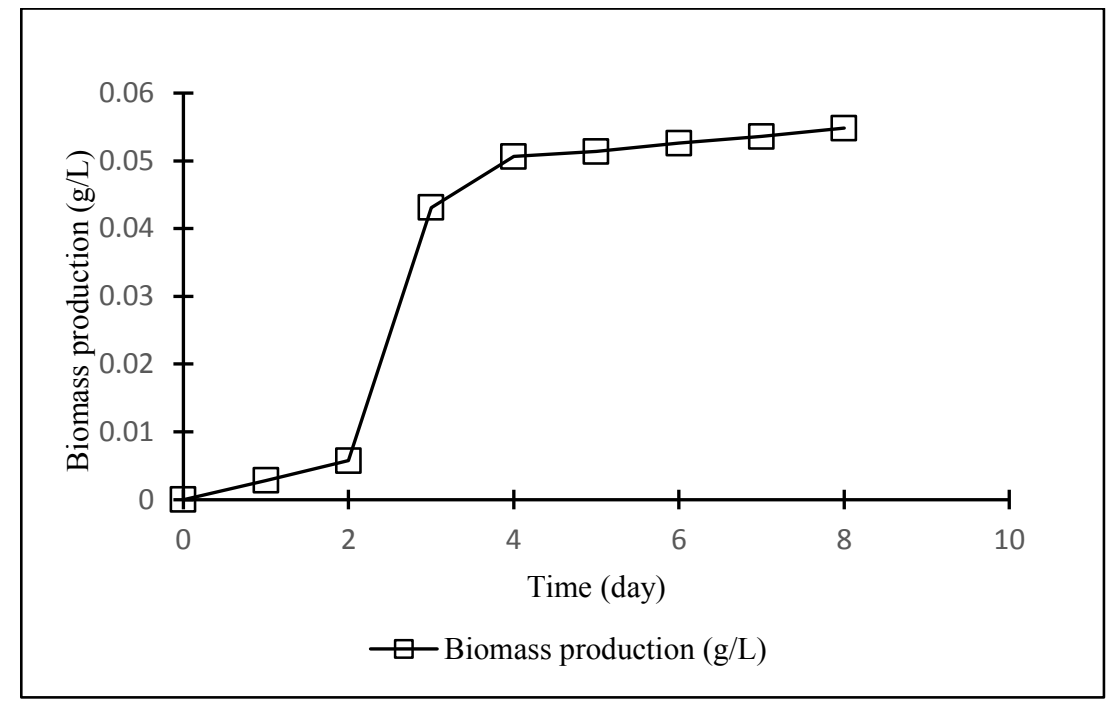

Figure 1. Biomass production of Ceratocystis fimbriata in mineral salt medium supplemented with OPF juices as a sole substrate for 8 days of fermentation

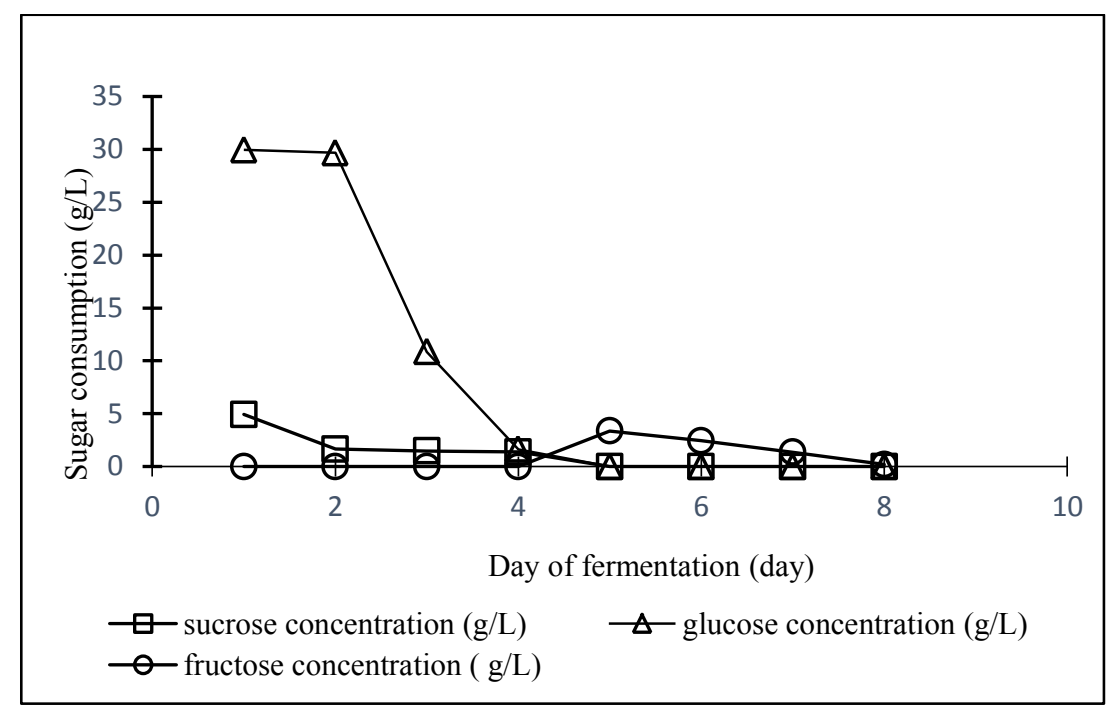

Figure 2. Glucose consumption profile for eight day of fermentation period by Ceratocystis fimbriata in mineral salt medium supplemented with OPF juice

In Figure 3(a), the seed culture was used as the inoculum in the fermentation of OPF juice. The seed culture was prepared at $27^{\circ} \mathrm{C}$ on a rotary shaker $(150 \mathrm{rpm})$ and incubated for eight (8) days. The inoculum was then transferred to the fermentation medium which consisted of $30 \mathrm{~g} / \mathrm{L}$ glucose in OPF juice supplemented with a synthetic medium. Figure 3(b), shows that the flask had one cell of mycelia after the first day of fermentation. With reference to Figure 3(c), after two days of the fermentation period, the fungus germinated to two big mycelium followed by third days of fermentation, it had seven mycelium cells. On the fourth day until the end of fermentation, the fungus germinated and had grown into many myceliums of cells. 

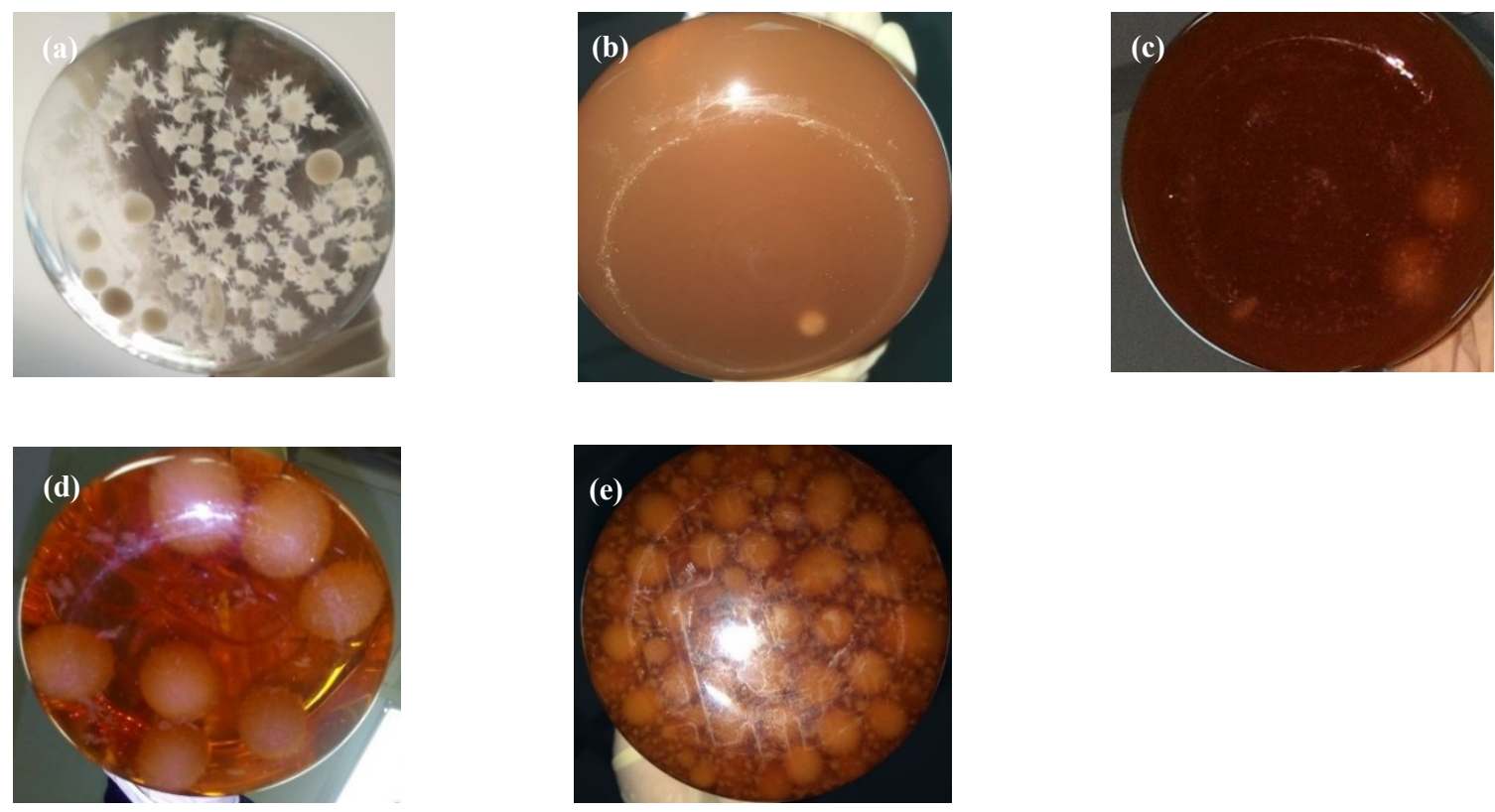

Figure 3. (a) Seed culture of Ceratocystis fimbriata in synthetic medium on the eight days of incubation. Ceratocystis fimbriata in $30 \mathrm{~g} / \mathrm{L}$ of glucose in OPF juice supplemented with synthetic medium (b) on the first day of fermentation, (c) second day fermentation, (d) third day of fermentation, (e) on the fourth day of fermentation.

From the fermentation of Ceratocystis fimbriata using OPF juice (as the sole carbon source), it was found that at least 45 peaks of compounds were detected by GC-MS SPME. The compounds were shown in Figure 4 and Table 1. The volatile compounds identified from fermentation of Ceratocystis fimbriata were mostly alcohol, phenol, ester, aldehyde as the major compounds. While other compounds such as alkane, alkene, ketone, amide, fatty acid and others were also produced during fermentation.

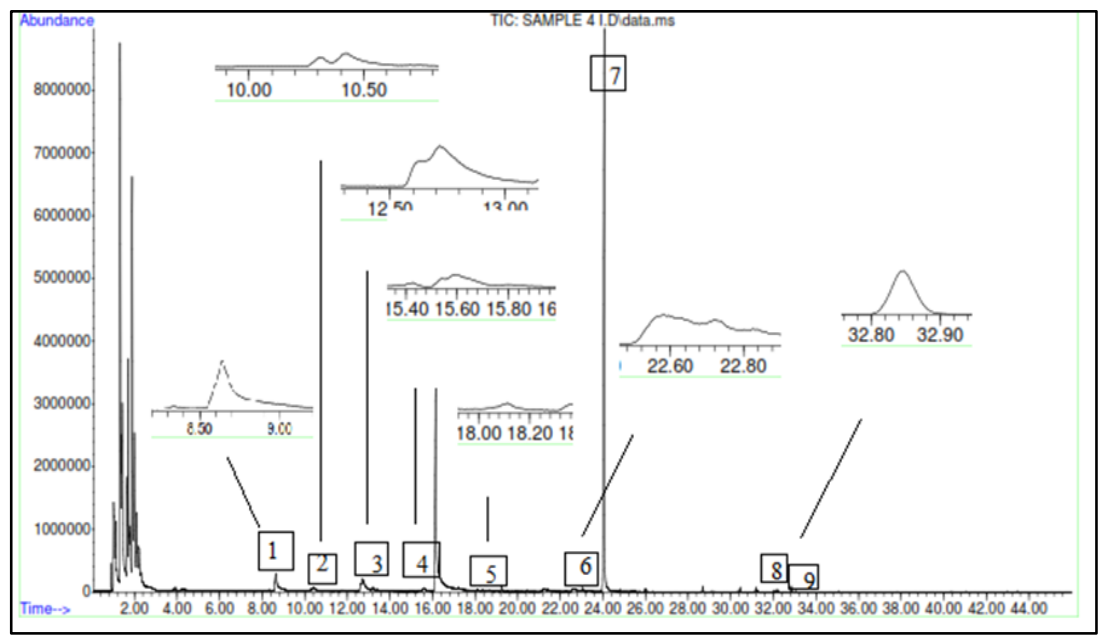

Figure 4. GC-MS with SPME analysis produced 9 peaks on the fourth day of fermentation. Peak (1) at the retention time 8.661, peak (2) at 10.421, peak (3) were the alcohol group at 12.732, peak (6) at the 22.643 and peak (9) at the 32.858 were the ester group, peak (4) at the 15.604 was the aldehyde group, peak (5) at the 18.107 was fatty acid, peak (7) at the 24.044 was the phenol group and peak (8) at the 32.174 was the ketone group. 
Table 1. Volatile organic compounds produced by Ceratocystis fimbriata using OPF juice as the sole carbon source

\begin{tabular}{|c|c|c|c|c|}
\hline Day & No & $\mathbf{R}_{\text {time }}$ & Area (\%) & Volatile organic compounds \\
\hline \multirow[t]{4}{*}{1} & 1 & 18.589 & 0.84 & 2-Methoxy-4-vinylphenol \\
\hline & 2 & 21.225 & 0.60 & 2-(4-ethoxyphenyl)-2-methyl-propanal, \\
\hline & 3 & 24.033 & 14.69 & 2,4-bis(1,1-dimethylethyl)- phenol, \\
\hline & 4 & 32.832 & 0.21 & Methyl 3-(3,5-di-tert-butyl-4-hydroxyphenyl)propionate \\
\hline \multirow[t]{4}{*}{2} & 1 & 15.582 & 0.58 & 3,4-dihydroxybenzyl alcohol, tris (trimethylsilyl) \\
\hline & 2 & 18.369 & 0.69 & P-tert-butyl- phenol \\
\hline & 3 & 21.231 & 1.36 & 2-benzothiazolecarboxaldehyde \\
\hline & 4 & 23.621 & 0.31 & 2,4-bis(1,1-dimethylethyl)- phenol \\
\hline \multirow[t]{5}{*}{3} & 1 & 8.688 & 2.47 & $1-$ Octen-3-ol \\
\hline & 2 & 12.774 & 1.49 & Dimethyl(isopropyl)silyloxycyclohexane \\
\hline & 3 & 24.033 & 29.01 & 2,4-bis(1,1-dimethylethyl)- phenol \\
\hline & 4 & 31.184 & 0.09 & 2-(1-phenylethylidene)- hydrazinecarbothioamide \\
\hline & 5 & 32.826 & 0.16 & Methyl 3-(3,5-di-tert-butyl-4-hydroxyphenyl)propionate \\
\hline \multirow[t]{9}{*}{4} & 1 & 8.661 & 2.40 & 1-Octen-3-ol \\
\hline & 2 & 10.421 & 0.95 & 2-ethyl-1-hexanol \\
\hline & 3 & 12.732 & 2.50 & Phenylethyl Alcohol \\
\hline & 4 & 15.604 & 0.47 & 3,4-dimethyl- benzaldehyde \\
\hline & 5 & 18.107 & 0.67 & Nonanoic acid \\
\hline & 6 & 22.643 & 0.71 & (Dimethylsilylene) bismethanol diacetate \\
\hline & 7 & 24.044 & 19.42 & 2,4-bis(1,1-dimethylethyl)- phenol \\
\hline & 8 & 32.174 & 0.08 & 7,9-di-tert-butyl-1-oxaspiro[4,5]deca-6,9-diene-2,8-dione \\
\hline & 9 & 32.858 & 0.15 & Methyl 3-(3,5-di-tert-butyl-4-hydroxyphenyl)propionate \\
\hline \multirow[t]{6}{*}{5} & 1 & 4.339 & 2.67 & (Z)- 3-hexen-1-ol \\
\hline & 2 & 12.694 & 10.98 & Phenylethyl Alcohol \\
\hline & 3 & 15.588 & 0.88 & 3,4-dimethyl- benzaldehyde \\
\hline & 4 & 21.241 & 0.70 & Ethyltriethoxysilane \\
\hline & 5 & 24.022 & 27.09 & 2,4-bis(1,1-dimethylethyl)- phenol \\
\hline & 6 & 32.832 & 0.26 & Methyl 3-(3,5-di-tert-butyl-4-hydroxyphenyl)propionate \\
\hline \multirow[t]{7}{*}{6} & 1 & 8.682 & 2.06 & 1-Octen-3-ol \\
\hline & 2 & 12.694 & 8.45 & Phenylethyl Alcohol \\
\hline & 3 & 15.593 & 0.78 & 3,5-dimethyl- benzaldehyde \\
\hline & 4 & 19.909 & 0.13 & Oxalic acid, isobutyl nonyl ester \\
\hline & 5 & 24.038 & 35.54 & 2,4-bis(1,1-dimethylethyl)- phenol \\
\hline & 6 & 32.158 & 0.15 & 7,9-Di-tert-butyl-1-oxaspiro(4,5)deca-6,9-diene-2,8-dione \\
\hline & 7 & 32.826 & 0.22 & Methyl 3-(3,5-di-tert-butyl-4-hydroxyphenyl)propionate \\
\hline \multirow[t]{4}{*}{7} & 1 & 12.716 & 6.74 & Phenylethyl Alcohol \\
\hline & 2 & 15.593 & 0.80 & 2,6-Dimethylbenzaldehyde \\
\hline & 3 & 19.899 & 0.18 & 2,6,10-trimethyl-dodecane \\
\hline & 4 & 24.039 & 42.11 & 2,4-bis(1,1-dimethylethyl)- phenol \\
\hline \multirow[t]{6}{*}{8} & 1 & 8.693 & 2.43 & 1-Octen-3-ol \\
\hline & 2 & 11.737 & 1.56 & cis-Linalool Oxide \\
\hline & 3 & 14.272 & 1.11 & 1,4-dimethoxy- benzene \\
\hline & 4 & 16.139 & 18.21 & $1,3,5$-Trioxane \\
\hline & 5 & 19.968 & 0.36 & 1,2,4-Trimethoxybenzene \\
\hline & 6 & 24.033 & 37.05 & 2,4-bis(1,1-dimethylethyl)- phenol \\
\hline
\end{tabular}


Based on the GC-MS SPME analysis, eleven peaks were classified as alcohols from the second day until the eighth day. The compounds include 3,4-dihydroxybenzyl alcohol, tris (trimethylsilyl); 1-octen-3-ol; 2-ethyl-1-hexanol; phenylethyl alcohol and (Z)- 3-hexen-1-ol. As commonly known, alcohols do not play a predominant role in flavors but are known to contribute to the overall flavors quality and are precursors of fruit-like flavoring esters [12] In microorganisms, all alcohol, except ethanol is formed by the reduction of $\alpha$-keto acids which are derived from amino acids metabolism [13].

Phenolic compounds were also detected consisting of 2-methoxy-4-vinylphenol; p-tert-butyl- phenol and 2,4bis(1,1-dimethylethyl)- phenol on the first day until the eighth day of fermentation. Six peaks were recorded as ester between the first day until the sixth day of fermentation except for the second day.

The esters comprised of methyl 3-(3,5-di-tert-butyl-4-hydroxyphenyl) propionate; (dimethylsilylene) bismethanol diacetate and oxalic acid, isobutyl nonyl ester. On the fourth day of the fermentation period, there were two ester group was present, which are methyl 3-(3,5-di-tert-butyl-4-hydroxyphenyl) propionate and (dimethylsilylene) bismethanol diacetate. After six days of fermentation period, the ester group found are methyl 3-(3,5-di-tert-butyl-4hydroxyphenyl) propionate and oxalic acid, isobutyl nonyl ester. The ester group plays a pivotal role in enhancing the different fruit fragrances such as methyl-butyrate (apple fragrance), methyl butanoate (pineapple), ethyl butyrate (orange), ethyl butanoate (pineapple), pentyl-butyrate (pear) and pentyl-butanoate (apricot) [14].

Four aldehydes were detected from the six peaks of compounds during the fermentation period except on the third day and the eighth day of fermentation. These aldehydes are methyl, 2-(4-ethoxyphenyl)-2- propanal; 2benzothiazolecarboxaldehyde; 3,4-dimethyl-benzaldehyde; 3,5-dimethyl-benzaldehyde and 2,6-dimethylbenzaldehyde. Three alkanes were recorded including dimethyl (isopropyl)silyloxycyclohexane on the third day; 2,6,10-trimethyl- dodecane on the seventh day and 1,3,5-trioxane on the eighth day.

Forty-five peaks were recorded during the fermentation which correspond to 11 alcohols, 10 phenols, 7 esters, 6 aldehydes, 3 alkanes, 2 ketones, 2 alkenes, 1 amide, 1 fatty acid and 2 others. During the fermentation process, the volatile compounds were produced from the first day until the eighth day of the fermentation period, however more volatile compounds were produced after the fourth day of fermentation period compared to the other day (Table 2). With reference to the past study which had used coffee husk as a substrate, the major compound produced by Ceratocystis fimbriata were ethyl acetate, ethanol and acetaldehyde [15]. Other compounds, including ethylpropionate, propylacetate, ethyl isobutyrate, butyl acetate was also produced during fermentation [15].

Table 2. Volatile organic compounds produced by Ceratocystis fimbriata using OPF juice as the sole carbon source for 8 days of fermentation (summarized from Table 1)

\begin{tabular}{|c|c|c|c|c|c|c|c|c|}
\hline $\begin{array}{l}\text { Fermentation Period } \\
\text { (day) }\end{array}$ & Alcohols & Esters & Aldehydes & Phenols & Alkanes & Alkenes & Ketones & Others \\
\hline $1^{\text {st }}$ & & 1 & 1 & 2 & & & & \\
\hline $2^{\text {nd }}$ & 1 & & 1 & 2 & & & & \\
\hline $3^{\text {rd }}$ & 1 & 1 & & 1 & 1 & & & 1 \\
\hline $4^{\text {th }}$ & 3 & 2 & 1 & 1 & & & 1 & 1 \\
\hline $5^{\text {th }}$ & 2 & 1 & 1 & 1 & & & & 1 \\
\hline $6^{\text {th }}$ & 2 & 2 & 1 & 1 & & & 1 & \\
\hline $7^{\text {th }}$ & 1 & & 1 & 1 & 1 & & & \\
\hline $8^{\text {th }}$ & 1 & & & 1 & 1 & 2 & & 1 \\
\hline Total no. of compounds & 11 & 7 & 6 & 10 & 3 & 2 & 2 & 4 \\
\hline
\end{tabular}




\section{Nang Nor Azimah et al: PRODUCTION OF VOLATILE ORGANIC COMPOUNDS USING OIL PALM \\ FROND JUICE AS A SOLE SUBSTRATE BY Ceratocystis fimbriata}

Another researcher found that nine volatile compounds were detected when citric pulp was used as the substrate in fermentation. These compounds are acetaldehyde, ethanol, ethyl acetate, propyl acetate, ethyl isobutyrate, 2hexanone, 2-hexanol, isoamyl acetate and one unidentified compound [16].

\section{Conclusion}

Based on the results and discussion, it can be concluded that volatile organic compounds can be produced from the utilization of OPF juice as the carbon source by Ceratocystis fimbriata. With reference to the GC-MS SPME analysis, the highest number of VOCs ( 3 alcohols, 1 aldehyde, 1 fatty acid, 1 phenol, 1 ketone and 2 ester) were produced by Ceratocystis fimbriata on the fourth day of the fermentation period. For future work, further investigation on the parameters affecting volatile organic compounds production from OPF juice by Ceratocystis fimbriata will be look upon to improve the yield.

\section{Acknowledgement}

The author would like to be obliged to Universiti Malaysia Pahang (UMP) for providing laboratory facilities and financial assistance under UMP Grant Scheme project no. RDU 150315 and PGRS160324.

\section{References}

1. Ariffin, H., Abdullah, N., Umi Kalsom, M. S., Shirai, Y. and Hassan, M. A. (2006). Production and characterization of cellulase by Bacillus pumilus EB3. International Journal of Engineering and Technology, 3(1): 47-53.

2. Ariffin, H., Hassan, M. A., Umi Kalsom, M. S., Abdullah, N. and Shirai, Y. (2008). Effect of physical, chemical and thermal pretreatments on the enzymatic hydrolysis of oil palm empty fruit bunch (OPEFB). Journal of Tropical Agriculture and Food Science, 36(2): 259-268.

3. Roslan, A. M., Yee, P. L., Shah, U. K. M., Aziz, S. A. and Hassan, M. A. (2011). Production of bioethanol from rice straw using cellulase by local Aspergillus sp. International Journal of Agricultural Research, 6(2): 188-193.

4. Ariffin, H., Hassan, M. A., Umi Kalsom, M. S., Abdullah, N., Ghazali, F. N. and Shirai, Y. (2008). Production of bacterial endoglucanase from pretreated oil palm empty fruit bunch by Bacillus pumilus EB3. Journal of Bioscience and Bioengineering, 106(3): 231-236.

5. Rushdan, I. (2002). Chemical composition of alkaline pulps from oil palm empty fruit bunches. Oil Palm Bulletin, 44: 19-24.

6. Zahari, M. A. K. M., Zakaria, M. R., Ariffin, H., Mokhtar, M. N., Salihon, J., Shirai, Y. and Hassan, M. A. (2012). Renewable sugars from oil palm frond juice as an alternative novel fermentation feedstock for valueadded products. Biosource Technology, 110: 566-571.

7. Maail, C. M. H. C., Ariffin, H., Hassan, M. A., Shah, U. K. M. and Shirai, Y. (2014). Oil palm frond juice as future fermentation substrate: A feasibility study. BioMed Research International, 2014: 1-8.

8. Morath, S. U., Hung, R. and Bennett, J.W. (2012). Fungal volatile organic compounds: A review with emphasis on their biotechnological potential. Fungal Biology Reviews, 26(2-3): 73-83.

9. Korpi, A., Järnberg, J. and Pasanen, A. L. (2009). Microbial volatile organic compounds. Critical Reviews in Toxicology, 39(2): 139-193.

10. Bigelis, R. (1992). Flavor metabolites and enzymes from filamentous fungi. Food Technology, 46: 151-161.

11. Medeiros, A. B. P., Pandey, A., Vandenberghe, L. P. S., Pastore, G. M. and Soccol, C. R. (2003). Coffee residues as substrates for aroma production by Ceratocystis fimbriata in solid state fermentation. Brazilian Journal of Microbiology, 34: 245-248.

12. Christen, P., Meza, J. C. and Revah, S. (1997). Fruity aroma production in solid state fermentation by Ceratocystis Fimbriata: Influence of the substrate type and the presence of precursors. Mycological Research, 101(8): 911-919.

13. Welsh, F. W., Murray, W. D. and Williams, R. E. (1989). Microbiological and enzymatic production of flavor and fragrance chemicals. Critical Reviews in Biotechnology, 9(2): 105-169.

14. Zawirska, W. R., Siwulski, M., Mildner, S. S. and Erwin, W. E. (2009). Studies on the aroma of different species and strains of pleurotus measured by GC/MS, sensory analysis and electronic nose. Acta Scientiarum Polonorum : Technologia Alimentaria, 8: 47-61. 
15. Medeiros, A. B. P., Pandey, A., Vandenberghe, L. P. S., Pastore, G. M. and Soccol, C. R., (2006). Production and recovery of aroma compounds produced by solid-state fermentation using different adsorbents. Food Technology and Biotechnology, 44(1): 47-51.

16. Rossi, S. C., Vandenberghe, L. P. S., Pereira, B. M. P., Gago, F. D., Rizzolo, J. A., Soccol, C. R. and Medeiros, A. B. P. (2009). Improving Fruity Aroma Production by Fungi in SSF using Citric Pulp. Food Research International, 42 (4): $484-486$. 